\title{
The Contributions of the Christian Missionaries in Building the Nigerian Nation, 1840-1960
}

\author{
Okpalike, Chika J. B. Gabriel \\ Department of Religion and Human Relations, Nnamdi Azikiwe University, Awka, Nigeria \\ cg.okpalike@unizik.edu.ng \\ Nwadialor, Kanayo Louis \\ Department of Religion and Human Relations, Nnamdi Azikiwe University, Awka, Nigeria \\ nwadialorkanayo@yahoo.com
}

\section{Doi:10.5901/ajis.2015.v4n2p159}

\section{Abstract}

Much of the existing works on the history of the evolution of modern Nigeria seem to be concentrated on the activities of three principal bodies from Britain: the British explorers, the British traders and the British colonial administrators. Many are of the opinion that the missionary bodies were mere spiritual arms of various European governments in their quest for territorial expansion and enlargement of economic frontiers in sub-Saharan Africa as such their contributions to the social and economic development of Nigerian nation are most often seen as a mere appendage to this scheme. Nevertheless, the galvanizing of the diverse people of Nigeria may not have been achieved by the mere order of British royalty. Even the tools of military, economic and political impositions were not enough to nurture a national consciousness. There was the wrestling down of traditional cultural/tribal consciousness, educational re-tooling of the mind and the personnel training in preparation for nationhood. This is the gap that this paper has filled. The missionary activities in Nigeria, especially their educational programs helped to whip-up the consciousness of a shared identity and helped to train a new set of elite that championed the course of nationalism and constituted a virile leadership for the young nation at independence. The paper made copious use of recorded history of missionary involvement in shaping the society and training its first generation of leaders and of observable evidences of continued impact of the emergent churches on the social, cultural, political and economic life of present-day Nigeria.

Keywords: Nation building, Christian missionaries, Nigerian experience, Nationalists, Bible and Plough.

\section{Introduction}

A nation can be defined as a political-territorial unit which contains a collection of cultural units with a set of cultural traits such as customs, beliefs or languages, and having functional inter-dependence. It is not necessarily that these units be homogenous; what is imperative is that there must be a sense of inter-dependence. Implicit in this definition is the existence of an external force which enables the cultural units to accept themselves as having an identity of shared fate. It is this identity of shared fate that sets the boundary of a nation or which differentiates one national group from another. The above analysis presupposes the influence of an external force(s) in the process that gave birth to the modern Nigerian nation. However the process of the evolution of modern Nigeria has generally been analyzed in the light of the British administrator, the explorer and the trader, the missionary receiving no more than a casual observation, yet it was the missionary propaganda that prepared the way for the governor, the explorer and the trader. Again Christian missionaries who had been active in Nigeria since the 1840s had encouraged their converts in the creation of a modern nation state that would take its place in the comity of nations. At an early stage the missionaries developed positive aims to create a strong and modern society capable of transforming the lives of the people - economically, educationally and socially to enable them to take their place as equals in the world community. Furthermore, the bringing together of the various groups by the missionaries themselves within a common ecclesiastical unit fostered the spirit of oneness and a sense of unity. These factors combined with the underlying unity already provided by centuries of contact (through trade, wars, and cultural interaction) amongst the various Nigerian communities began to create a common consciousness as the basis of the new nation (Olusanya, 1999). Apart from the gradual development of common consciousness brought about by the factors outlined above, there were other factors favourable to the emergence and growth of Nigerian nation. There was, for instance the desire of the people for self-rule in the Church affairs which implies freedom from foreign 
control; an idea sown as seed as early as the 1840s by Henry Venn, the then honorary secretary of the Church Missionary Society (C.M.S.) from 1841-1872. However, this is the point often missed by scholars who have investigated the process of the evolution of modern Nigeria. The missionary contributions to the general socio-economic and political development of modern Nigeria are always down played. It is for the above mentioned problems that this research work is conceived to put in proper perspective the place of the missionary in the making of a modern Nigerian nation. The research, among other things, is an attempt to shed the much needed light on an unnecessarily dark corner of Nigerian political and social history, so as to clarify this aspect of Nigerian history which has played many faceted parts in shaping modern Nigeria and which, both at the time and more recently, has had over simplified and stereotyped interpretations.

In the period under review there were five principal missionary societies working in Nigeria: the Anglican Church Missionary Society (C.M.S.), the Wesleyan Methodist Missionary Society, the Foreign Mission Committees of the United Presbyterian Church of Scotland, the Foreign Mission Board of the Southern Baptist Convention of the United States, and the Catholic Society of African Missions (S.M.A) of France. There were some important differences between the different missionary societies, both of doctrine and approach, each mission tended to emphasize how much it differed from all the others. However, from the point of view of the present researchers what they had in common was far more impressive. In this work therefore, the different missionaries will be considered as much as possible together as European missionaries forming one single factor in the history of Nigeria. The evangelistic work of the missions at this period may be patchy, but in their linguistic and educational work, in their economic policies, and above all, in the class of western educated elite they were seeking to create, their influence covered the whole country.

\section{A Background History of Modern Nigeria: The Missionary Perspective}

Prior to the advent of the missionaries and the British colonialists, Nigeria as a socio-political entity was neither in existence nor contemplated, the territories that now make up the modern Nigeria existed in fragments. There were the Benin Empire, the lower Niger kingdoms, the Fulani Empire of Zodge (later known as Sokoto), and the Kanem-Borno Empire. There were also the Oduduwa Empire of the Yoruba, and the Aro-Chukwu Empire of the Igbo, there was also the Aboh Kingdom that sprang from the Benin Empire. There were no systematic contact between one empire and the other. There were however, isolated trade contacts, particularly among the people of the lower Niger kingdoms and the Benin Empire.

The creation of modern Nigeria is traceable to the activities of three different groups, namely, British missionaries, traders, and imperialist. From a chronological perspective, the first of these activities was the British anti-slavery movement which curbed the exportation of African slaves and the colonization of Lagos between 1851 and 1861. At the end of 1851, after two artillery battles, the British established a consulate in the tiny Awori Kingdom of Eko (Lagos). The background to this has been interpreted in terms of the humanitarian desire to end the slave trading, and of commercial self interest. Both factors were present, but another important element was the long political struggle within the royal house, which had lasted for half a century. The weaker contestant, Akitoye, signed an anti slavery agreement and thus enlisted British aid against his vigorous and ambitious rival, Kosoko. After ten years of consular presence in which the king seemed increasingly a mere puppet, a colony was established in 1861, which was expanded in the 1880's and 1890s to create the Colony and Protectorate of Lagos and Yorubaland.

The activities of traders and missionaries in the Oil Rivers followed. In 1883, the French established a Protectorate over Port Novo. In 1884 a German representative obtained treaties of cession in the Cameroons. Isichei (1983) believes that it was feared that the establishment of other colonial jurisdictions would lead to the expulsion of British merchants as trade was then their major object in West Africa, and if they remain passive they shall see their trade stifled, they shall find their traders furious, and they shall hardly escape grave complications with the French. To avoid such calamities, they evolved the scheme for keeping the French away from the Niger and Oil Rivers. In the Delta, the Consul, now stationed at Calabar, bolstered his position by treaties with local rulers which culminated in the creation of the Protectorate of Southern Nigeria in 1900.

Finally, were the imperialist activities of the Royal Niger Company. On the Niger, the various competing British firms were united into one by a man history knows as Sir George Goldie. The resulting single firm then received a charter to govern as the Royal Niger Company, a charter which lasted from 1886 to the end of 1899. To the British government, it had the great advantage of maintaining an effective presence on the Niger, which excluded other nations, at no cost to the British taxpayer. After the revocation of its charter by the British Government, they created the Protectorate of Northern Nigeria in 1900.

The territory known today as Nigeria began its match to nationhood in 1861. In that year, Okeke (2010) posits that 
the king of Lagos, Dosumu was made to sign away the political independence of his territory to Britain. With threats of bombardment and other acts of intimidation, the imperial Britain succeeded in making the pliant king to succumb to its desire to control the politics and economy of Lagos. By this act, Lagos with its territory became a Crown Colony of Britain. Before this period, British Consuls had established offices first along the coast and later in other parts of what is today known as Nigeria. These Consuls coordinated the activities of British merchants who were involved in trading activities along the banks of the Niger and Benue rivers. In 1879, Sir George Goldie and Mr. Hawith, a Consul, requested the government of Britain to declare the lower and Delta areas of the Niger a British Colony. In response to this, as noted above, the British government granted Sir Goldie's trading company a charter of administration over territories along the Niger and Benue rivers for a period of ten years. To consolidate the territorial gains of Goldie, Britain sent Fredrick Lugard to assist in the establishment of British trade monopoly there. Lugard was a soldier and former colonial administrator in Nyasaland (now Malawi) and Uganda. At this time of his deployment, France was posing a threat to British interest in the territories of what later became Nigeria and was pushing towards them through Dahomey (now Benin Republic). As a well experienced soldier, Lugard was equal to the task of halting the French advances. In 1898, this territorial quarrel between Britain and France ended with the signing of Anglo-French agreement (Forsyth, 1977). These events led to the establishment of the following British territories in what later became known as Nigeria - the Lagos Colony, the Oil Rivers Protectorate and the Northern Protectorate. The Oil Rivers Protectorate was extended in 1893 and proclaimed as the Southern Protectorate and Ralph Moor was its Governor (Okeke, 2010). The Royal Niger Company was granted a charter of administration over the Northern Protectorate until 1900 when the British government took it over and placed it under the supervisory control of Fredrick Lugard. In May, 1900, the colony of Lugard was merged with the Southern Protectorate and Walter Egerton was made its Governor. At this time, Lugard was also made the Governor of Northern Protectorate. Two administrative entities were thus created by imperial Britain to suit the political and economic interests of British government and merchants. In January 1914, the Northern and Southern Protectorates were amalgamated and became one British colony. Fredrick Lugard was made its first Governor General. A name was now needed for the colony and a British reporter, Flora Shaw, who was later married to Fredrick Lugard suggested the name Nigeria, to be named after the Niger River meaning Niger Area.

This brief account of colonial Nigeria shows that the society is an aggregation of desperate tribal bands held together by a superior transcendental authority of the colonial power. It was simply an imposition of a transcendental administration on a collection of peoples who had little or nothing in common with other collectivities. Etzion (cited by ljeomah, 2011) describes them as units which were stronger than the system. The system was a collection of tribal units which had minimal interaction. However, it was the missionaries who conceived the idea of a modern Nigeria that would embrace the myriads of empires and kingdoms of the pre-colonial era. Their teaching of universal brotherhood was a decisive factor in the coming together of these desperate tribal bands to form a common nation. From the start the C.M.S. papers reveal in bold relief that the linguistic and ethnic groups represented in Sierra Leone in the middle $19^{\text {th }}$ century included the Hausa, the Kanuri, the Kakanda, the Nupe, the Igbo, the Efik, the Yoruba, the Marghi and the Basa, to name a few. The missionaries made themselves spokesmen for Nigeria, and the emergent Nigerian nation is a fulfillment of their dream. According to Wyse (1988):

The Sierra Leone Creole is a peculiar portion of the African race. The Creole forms a distinct nationality. It cannot be predicted of him that he is Aku or Eboe or Hausa. No indeed, he is the embodiment of African tribes, a representative individual of a peculiar character. His function is to bring together the various tribes into one composite tribe, to cement them and to render obsolete tribal traits peculiarities and idiosyncrasies. (p. 21).

In examining the relationship between the various tribal groups and empires in Nigeria we argue that Christianity tends to bring people of different groups together. At Church conferences, Christians met fellow Christians from other ethnic groups. Christians from different areas and denominations came to worship together which led this band of erstwhile different and warring ethnic groups to perceive themselves as one, and to mobilize, their differences notwithstanding. Such integration was indispensable if the units were to form a national unit. A national unit, according to ljeomah (2011) "is a macro-structure in which the interdependent micro units are bound together by extended loyalties, values, symbols and consensus" (p. 21). It is the group in which there is functional interaction as well as shared values. It is contended here that it is only in such an integrated social unit that nation building may have a meaningful discussion. Thus, the missionaries could be said to be more concerned with the patterns of human relations which facilitated the process of development of national consciousness. These collectivities with little or no contact with their neighbours would hardly have developed a common orientation towards any national symbol. Thus the missionaries in Nigeria can be said to have grouped fatherlands together. The fatherland is the heritage handed down to us by our ancestors. The fatherlands are the Fulani and Hausa Empires, the Yoruba Empire, the Igbo and Ibibio Empires, the Edo and Tiv 
Empires, and so on. Just as the tribe is made up of many families, so the nation is made up of many tribes, and as the tribes were originally isolated and oriented towards parochialism and disintegrative ethnicity, the promoters of the new religion are cosmopolitan in outlook.

\section{The Establishment of Christianity in Nigeria}

After the failure attempt to plant effective Christianity in Nigeria in the $14^{\text {th }}$ and $15^{\text {th }}$ centuries by the Portuguese Roman Catholic missionaries, the successful expansion of the Christian missions in Nigeria began in the $19^{\text {th }}$ century. The first half of that century witnessed a revolution in European attitudes and policies towards West Africa. It is pertinent at this point to state the hard fact of history that the principal relation between the industrialized nations of the west and tropical Africa for many centuries was the trade in slaves carried on mainly by Christian peoples of Western Europe and Arabs. According to Anene (1999):

The establishment in the New World of European plantations for the large-scale production of sugar, cotton and tobacco necessitated the search for cheap and abundant labour. The local Indians were being wiped out through subjection to arduous plantation labour and it was out of solicitude for these Indians that Bishop Las Casas petitioned the Holy Roman Emperor to allow the importation of Negro slaves. (p. 100).

The British who had acquired many islands in the Caribbean realized that the islands were suitable for the production of sugar. The demand for labour for the care of the cane and its harvesting for processing into sugar and rum could be met by importing Negroes. However, after nearly three centuries of callous indifferences to Negro suffering the conscience of religious and humanitarian groups in Western Europe and America was roused against the iniquitous traffic. The protracted struggle to end the Trans Atlantic slave trade registered its first decisive victory in 1807, when Britain, the most powerful industrial and maritime power of the day, proscribed the trade to her citizens. It would be expected that the abolitionists had won a legal victory, but legal enactment was not effective enough to put a final stop to the inhuman activity. This was because several notable African chieftains who had thrived on slave trade were not in a hurry to stop the trade without any promise of an alternative profitable trade, and several other European nations like Spain, France, and Portugal had continued with a trade that had been proscribed by the British parliament. The British government decided to enter into treaties with the United States of America (USA) and other European countries to enable them enforce the parliamentary Act of May 1, 1807. Britain, therefore, authorized her Navy to capture foreign slave dealers on the high seas. The slaves thus captured were sent to Freetown in Sierra Leone. Thus Freetown became a conglomeration of people from several Nigerian and West African tribes. The Sierra Leone settlers were exposed to Christian doctrines and Freetown was to serve as a nerve centre for the spread of Christianity and civilization in West Africa.

The missionary activities of the various mission bodies who operated in Sierra Leone at the time were contemporaneous with the resolution of the British government that only by cultivating habits of industry and preaching the gospel of Christ could the Africans be redeemed and regenerated. At this time, Thomas Fowell Buxton, a British humanitarian, proposed the theory of the "Bible and the Plough" as the most effective way to redeem the liberated slaves. Okeke (2006) notes that:

Thomas Fowell Buxton believed that the most effective approach to the anti-slavery campaign was to involve the British government, humanitarians, interested businessmen and the British missionaries in a cooperative endeavour. The success of the venture they anticipated would mean a death-blow to the traffic in person. (pp. 4-5).

Onunwa (1991) recalls that the missionaries were convinced on how the "Bible and the Plough" hypothesis would serve the course of civilization and Christianity. They were to preach the gospel and to civilize the people. The argument was that it was Christianity that laid the foundation for European civilization, therefore if any meaningful civilization was to be fostered in Africa, is has to be based upon the foundation of Christianity. Following largely the spirit of the "Bible and plough hypothesis", the Christian missionaries generally were working together in the civilizing mission to Nigeria. Generally speaking, the form and pattern that modern Nigeria was to take was embedded in the "Bible and Plough" theory. The nation was one that could compete with others in the comity of nations. It was to be based on European model; it was to have a Christian foundation, weld several ethnic groups together and rest on a solid industrial base. The tool for the building of the nation-state would be Christianity, commerce and civilization. It then follows that it was the missionaries who first conceived the idea of a modern Nigeria; a project that was only accomplished by the British force of colonialism.

The missionaries also made education one of their chief means for the spread of Christianity in West Africa. Schools were established in the colonies where the converts were taught how to read and write. Apart from primary 
schools, secondary schools were built. In 1827, Fourah Bay Teacher Training College was built in Sierra Leone and was upgraded to the status of a University in 1876 and provided University education to students from various West African countries. Missionary activities thus carried with it building of schools, Churches, roads, hospitals, and of course other institutions of government. Several educationists, evangelists, and even nationalists were to evolve from this historical event. Several Nigerians quickly passed out of these mission founded schools. Some were adventurous enough to board ships to far away America, Europe and so on. Shortly after, these western educated Nigerians came back home to Nigeria and thus began the process of nation building.

\section{The Missionaries and Nation Building: The Nigerian Experience}

While it is true that Nigeria did not yet exist as a political unit in the middle $19^{\text {th }}$ century, the nearest approach to the Nigeria of today was to be found in C.M.S. circles because their mission fields were the likely basis of the new nation. In this regard, it can be argued that the C.M.S. mission gave Nigeria the shape that it later took. The missionaries of the C.M.S. desired that the British flag may be hoisted, especially within their areas of operation. It was their areas of operation that later became modern Nigeria.

The Christian missionaries were products of the new enlightenment age characterized by a belief in progress. This explains the Christian missionaries' commitment to the material, moral and political advancement of the so called unenlightened or uncivilized peoples. It should be borne in mind that social reform is implicit in the preaching of the Christian missionaries. Consciously, as a preacher of Christianity interpreted in the light of European social and political history and unconsciously, as a man produced by that particular environment, the missionary brought to Nigeria various aspects of European life. The missionaries who saw civilization as allied to Christianity attempted more than just a reform of the manners of the converted people. The products of the industrial revolution were by then beginning to reach down to the masses from among which many of the missionaries arose. When the missionaries talked about civilization, it was not so much the reform of the manners that they referred to as the temporal blessings which resulted from the spread of the Christian religion. Among these temporal blessings, political changes were most often included. This is in line with the type of political changes advocated by Earl Grey as preserved by Ajayi (1965) thus:

To keep constantly in sight the formation of a regular government on the European model and the establishment of civilized policy as the goal ultimately to be attained. The real interest of the missionaries is gradually to train the inhabitants of this part in the arts of civilization and government. (p. 16).

This civilization rests on Christianity, can be maintained by Christianity. In particular, the Christian missionaries introduced into Nigeria the idea of nation-building of contemporary Europe. Hence, Oduyoye (1978) would say that:

In spite of their pietistic theology, the early missionaries came from a culture which kept only one eye fixed on heaven, while the other was focused quite firmly on the earth. The advanced technology and high standard of living which were beginning to emerge as beneficial effects of the industrial revolution in the United Kingdom were regarded as benefits which God bestowed upon his Christian people. Therefore, in the first human relations between Britain and Nigeria, the sharp distinction between mission and trade was not strictly observed. (p. 264).

The missionaries also trained a group of Nigerians who accepted their idea of nation building and hoped to see them carried out, and later began to use these ideas as a standard by which to judge the actions of the British administration. Lewis, (cited by Oduyoye, 1978) states that:

Foreign influence may, indeed it must, for some time to come do much for Nigeria, but not least by recognizing the fundamental fact that when all has been said and done by Europeans and Americans that they can either say or do, the Nigerian himself is and must always remain the fittest instrument for the development of his country. He it is who can best be trained to utilize the vast resources of Nigeria, not only for her own good, but for the benefit of human race. (p. 287).

Thus, at independence in 1960, as a result of missionary training, the young nation, Nigeria inherited a civil and public services, staffed and led by some men and women who possessed the requisite skills, techniques, knowledge and attitudes to achieve the objectives of government by transforming paper plans into real practical services (Uruakpa, 1996). Thus missionary training succeeded in providing the intellectual, political and skilled man-power for nation buildings. It is essential to bear in mind, not only that this preceded the establishment of British rule, but also that it was undertaken in the belief that direct British rule was unlikely and that whatever social, political and economic changes were considered necessary in the country would have to be achieved by encouraging a new class of Nigerians themselves to reconstruct their own environment.

Undoubtedly, the Christian missionary societies who worked in Nigeria in the $19^{\text {th }}$ century as a whole sought to encourage their wards ultimately to create in Nigeria one or more states in the image of contemporary Europe. And the 
ideal of European nations they presented to them had three essential characteristics. First, European nations were Christian. Secondly, they were civilized in the technological sense of the industrial revolution; in particular, they had the marvel of steam power and railways. Thirdly, petty states had long ago given way to large, more powerful units, and where, as in Greece, Germany, and Italy, this development was little delayed, nationalist movements were already creating the larger units required for the full development of commerce and technology. The missionaries had these developments at the back of their minds and they urged them on their wards largely because they could not conceive of Christianity flourishing in a social or economic or even political environment that differed in essence from the European environment. They did not think of themselves actually building the nation. They therefore aimed only at initiating the revolution, raising Churches and training local men who would themselves build the new nation. Hence their emphasis on education and on raising a local staff, a local body of educated Nigerians. This emphasis was to a large extent due to the practical problem of the high rate of mortality among Europeans in West Africa and consequently to some amount of uncertainty as to the whole future of Afro-European relations. And thus from the practical need of providing African missionaries and auxiliaries, the European missionary societies began to think in terms of raising up an African middle class on the lines of Europe and America. Those would be the men to carry through the revolution initiated by the missionaries.

The supreme importance of Christian missions in Nigerian nation building lies in the fact that it was upon them, almost entirely that the socio-political development of Nigeria fell in the period under study. This is not to say that British administration had no political purpose for its presence in Nigeria. But, until the days of Lugard, the political purpose of British administration was purely negative. The administration justified its presence by creating law and order in place of inter-tribal wars and anarchy, and by suppressing abominable crimes repugnant to Christian morality. The immense value of this effort on the part of the administration is not to be underrated. It did not only facilitated mobility and inter-tribal mingling, but also made it safe for anyone to travel about freely without the risk of being enslaved in any part of the country. But the administration was mainly engrossed with economic matters - the development of the imperial estate. It is against this background that the efforts of Christian missions in the development of modern Nigeria can be clearly appreciated. They sought to effect a social regeneration through their Churches and schools; on this they won the universal approbation of nation builders.

Before 1900 the western form of education was appreciated and patronized since Nigerians looked upon mission education as the only agency that could bring about the social and political revolution they envisaged for Nigeria. It is not surprising then that mission schools were largely welcomed in most parts of Nigeria. To this Ayandele, (1966) opines that the concentration of intellect in the Church provided a moderating influence to Nigerian nation building. According to Ajayi (1965):

When the first mission schools were established at most of the centres, the majority of the missionaries had still to learn the local languages; the emigrant schoolmasters had themselves been brought up in English, which they saw as the language of commerce and civilization, the road of success and advancement. (p. 139).

By the aid of the missionaries and schools, English language became the common medium of communication of all Nigerian tribes as the Roman language was to the modern nations of Europe. In this way the Church became an integrative bond uniting individuals of different and formerly hostile communities.

The two largest Christian missions in Nigeria (the Church Missionary Society and the Roman Catholic Mission) distributed their evangelizing efforts among virtually all the provinces and groups in Nigeria. Annual Church conferences attended by Nigerian clergy men and lay agents of diverse cultural backgrounds helped to break down parochialism and awakened a wider view and a consciousness of racial identity. Moreover, in the rapidly growing multi-tribal urban communities Christian Churches provided a link among converts of different tribes and a new basis of loyalty in which ethnic origin became less relevant.

As the missions had a monopoly over education, the Christians in urban communities included most of the educated Christians, who were later to become the leaders in protest movements and in the awakening of a political and trans-tribal national consciousness. Webster (1977) maintains that outside the Church, multi-ethnic organizations were not easy to be established.

\section{Tools for Nation Building employed by the Missionaries}

1. The Development of Nigerian Indigenous Languages: One of the far reaching implications of the Christian missionary presence in Nigeria was the great studies which were made in the field of literacy. Indeed nothing shows the ardour of the pioneering missionaries better than the effort devoted, within the limited resources of 
the missions and the ability of the missionaries, to the study of the principal Nigerian languages, reducing them to writing, in most cases for the first time. According to Ajayi (1965), "the driving force behind the work on the Nigerian languages was the anxiety to teach the converts and would-be converts to read the Bible in them" (p. 13). It was especially for this that so much emphasis was placed on translating the Bible into the vernaculars; the ability to commit some African languages to writing led to the translation of the Bible into the vernacular of many Nigerian societies. The literate Nigerians began to read the Bible in their own languages. The study of Nigerian languages began in Sierra Leone where several of the languages were represented among the liberated African slaves. As early as 1830, J.T. Rabon of the C.M.S., observing that the 'Aku', as the Yoruba were called, were fast becoming a majority in the colony, began a study of Yoruba with a view to facilitating evangelization within the colony. Okeke (2006) also observes that "in 1848, Fourah Bay Institute which was almost languishing in the 1830's, was revived, and Edward Jones of African descent became the principal; the curriculum included West African languages" (p. 34). Furthermore, when arrangements were being made for the Niger Expedition and a mission was projected for the model farm at Lokoja, J.F. Schon, a German linguist and C.M.S. missionary, was charged with the duty of training interpreters and himself acquiring the languages he considered most essential. The languages he chose were Hausa and Igbo. For the same purpose Samuel Crowther intensified his study of his own language, Yoruba. The results of these studies were published in 1841. The other missions in Nigeria were also studying different languages in the country, comparing translations and discussing the orthography. Interest in Hausa and Igbo were intensified with Henry Barth's travel in Northern Nigeria and Macgregor Laird's mail contract to ascend the Niger by steamer in 1854. Attention was also paid to Kanuri. A brilliant German missionary of the C.M.S., S.W. Koelle, in 1854 published two works: Grammar of the Bornu or Kanuri language and African native literature in Kanuri which were of wonderful accuracy and interest. By the middle of the $19^{\text {th }}$ century this interest had come to take deep root. Between 1852 and 1900 over ten works had been published in the language, mainly by missionaries and their aids. Most of these were primers and grammars, a few were word list and collections of proverbs, while the remainders were translations of sections of the Bible into various dialects of the language. This trend continued, or rather broadened out with the increase in evangelical work which followed in the wake of the new political settlements. By the first decade of the $20^{\text {th }}$ century when Nigeria was thrown open to the missionaries and scholars, various primers and grammars and word lists had been published in the peripheral dialects of the various languages and thus, the languages began to acquire new prestige.

It must be conceded, therefore, that the missionaries rendered remarkable services to the development of Nigerian languages through reducing them to writing, through their numerous catechetical tracks in the vernacular and, through the translation of the Bible into them. The missionaries emphasized that it would be impossible to convey the gospel message effectively to any people unless the evangelist himself was able, not only to master the local tongue of the people but also to understand their thought and value system. It is possible that these considerations caused them to stress the importance of producing literature and teaching material in the vernacular. Although the vernacular literature, were first produced primarily for evangelistic considerations, it has also had considerable positive effects upon the building of the Nigerian nation.

2. The Development of Indigenous Journalism in Nigeria: In a sense, journalism which began in Nigeria from the 1850s in part derived their inspiration from the example of the European missionaries. The effective use to which the British humanitarian movement put the newspaper in the mobilization of opinion in favour of their programmes established the newspaper as an essential instrument of mission work outside Britain. According to Olukoju (1997), it was the C.M.S. that published in 1859 Nigerian's first newspaper, the Iwe Irohin, a fort nightly publication. An English language supplement was added in 1860. The Christian missionaries thus pioneered newspaper publishing in Nigeria, an industry that played a decisive role in the country's later history. Omu (1967) states further that not only did the C.M.S. inaugurated journalism in Nigeria, it also started the tradition of the large number of one room printing works in several large towns in Nigeria, some of who printed some of the early nationalist newspapers. The Christian missions also introduced a variety of journals and magazines published by the Church. Magazines such as African Church Gleaner, Nigerian Baptist and the African Church through which budding nationalists aired even their political views (Gbadamosi and Ajayi, 1999).

With larger city populations and a far greater number of people able to read, missionary newspapers and their demands for social and political reform were influencing more people than ever before. It became an important medium for the development a modern state in Nigeria R.B. Blaize of Oyo and Abeokuta parentage began the 
first Nigerian owned newspaper in 1880 known as Lagos Times. Twenty four months later, Lagos Observer surfaced. The Eagle and Lagos Critic emerged in 1883, and in 1887, The Mirror appeared. Nigerian's desire for the building of their nation in European manner was expressed through these print media. The newspapers aimed at uniting Nigerians and discussing vital issues which heralded an incipient nationalism and their call for Nigerian political representation. Its emphasis lay heavily with Nigerians in their revolt against indiscriminate European influence and their desire to play a greater role in the leadership of their country. The newspaper helped immensely in the education and information of the people on the need for the rejection of all traces of colonialism and advocated for self-rule. In a sense, the indigenous newspaper movement developed at the time it did partially because substantial members of skillful printers were available to undertake the printing of the newspapers. The newspapers introduced many educated Nigerians to what had become an intrinsic part of enlightened society in Europe and other lands and what was to become the chief weapon by which they were to exercise their power of participation in their own government. The emergence of the newspapers coincided with an important phase in the evolution of modern Nigeria.

From the foregoing, it is evident that the newspaper press that was introduced by the missionaries was an important influence in the evolution of modern Nigeria. Nationalist leaders like Nnamdi Azikiwe, Obafemi Awolowo and Samuel L. Akintola were reputed newspaper men inspired by the activities of the pioneer missionary pressmen. The newspaper press has helped in creating a tradition of fearless and energetic political journalism which underpinned the propaganda of the independent movement. They played a key role not only in stimulating intellectual activity and molding nationalist opinion but also in inculcating a spirit of criticism and resistance in future generations of Nigerian leaders.

\section{Conclusion}

From the second half of the $19^{\text {th }}$ century, Christian missionaries featured prominently in the series of events that led to the development of Nigerian nation, and were able to bring about certain political, economic and technological changes in the region. Their activities helped to break down ethnic prejudices and to bring their converts in loyalty transcending ethnic ties. Patriotic Nigerians came to believe that by practicing Christianity they were paving the way for the creation of the Nigerian nation. The Nigerian state of their dream was one in which Christianity would flourish, inter-tribal wars would cease and the industrial, technological and intellectual revolutions which had occurred in Europe would repeat themselves in Nigeria. By encouraging a common consciousness it would reduce to a minimum all other sectional loyalties such as the many incipient tribal groups that divided Nigeria in the empire.

The missionaries also gave ever increasing number of Nigerian adherents a powerful weapon through the provision of western education. Within the mission stations education was the main instrument used for establishing and maintaining the new values. Literacy was actively pursued as a means of gathering the converts to read the Bible for themselves. The Protestant missionaries emphasized the importance of responsible personal conviction and decision in religion as in other matters. Through their extensive missionary activities and long monopoly in the field of education, Christian missionaries played a critical role in the making of modern Nigeria. Unlike the European traders, they did not limit their endeavours to port towns, rail or river lines, or commercial centres; rather, they undertook to penetrate the most remote areas in the interior with the determination to remain there until Christianity was firmly established. Unlike government administrators, they did not seek to preserve traditional society, but rather to transform it; a process which brought about the emergence of educated elite in Nigeria. Hence, Coleman (1986) maintains that "without the missionary enterprise both the timing and nature of the awakening of national consciousness would probably have been very different" (p. 9). The desire for autonomy and independence of Nigerians in the missions Churches was the genesis of the development that crystallized into what was known later as Nigerian nationalism as well as the struggle for political independence.

In the final analysis therefore, the present researcher argues that for those who may wonder what may be the business of the Church in nation building, we are yet to see whether indeed Christians cannot fully identify with the people's struggle for genuine well-being without thereby losing the sense of the transcendent and metaphorical that is characteristic of all religion. Maduro (1982) puts it in another way: Is it really impossible for religion to be nucleus of popular resistance, something hope can feed on, a transforming goad to build a new world, in concert with all who long for, and on behalf of all who need, a new word?

This is the theme that this paper has addressed. 


\section{References}

Ajayi, J.F.A. (1965). Christian missions in Nigeria, 1841-1991: The Making of new elite. London: Longman.

Anene J.C. (1999). Slavery and the slave trade. In J.C. Anene \& G.N. Brown (Eds.). Africa in the nineteenth \& twentieth centuries (pp. 92-100). Ibadan: University

Ayandele, E.A. (1966). The missionary impact on modern Nigeria, 1842-1914: A political and social analysis. London: Longman.

Coleman, J.S. (1986). Nigerian background to nationalism. Benin City: Brobury and Wistron.

Forsyth, F. (1997). The making of an African legend: Biafra story. Enugu: Pengium.

Gbadamosi, T.G.O \& Ajayi, J.F.A (1999). Islam and Christianity in Nigeria. In O. Ikime (Ed.). Ground work of Nigerian history (pp. 347366). Ibadan: Heinemann.

Ijeomah, B.I.C (2011). Nigerian nationalism and the problem of social-political integration. Onitsha: Blueprints.

Isichei E. (1983). A history of Nigeria. London: Longman.

Maduro, O. (1982). Religion and social conflicts. New York. Orbis.

Oduyoye, .M.C. (1978). The planting of Christianity in Yorubaland, 1842-1888. In O.U. Kalu (Ed.). Christianity in West Africa: The Nigerian story (pp. 239-394). Ibabdan: Daystar.

Okeke, D.C. (2010). People of the book: The Anglican mission in Igboland (vol 1). Enugu: Rabboni.

Okeke, S. (2010). Nationalism and nation building in Nigeria: Trends and challenges. In N Okediadi, O. Uche \& S. Okeke (Eds). Themes in Nigerian peoples and culture (pp. 16-30). Enugu: John Jacob.

Olukoju, A. (1997). Christianity and the development of the Nigerian state. In A.

Osuntokun \& A. Olukoju (Eds.). Nigerian peoples and cultures (pp. 136-156). Ibadan: Davidson.

Omu, F.I.A (1974). Journalism and the rise of Nigerian nationalism: John Payne Jackson, 1848-1915. Journal of the Historical Society of Nigeria, vii, 3, 521-539.

Onunwa, U. (1991). Missionary factor in African nationalism. Indian Mssiological Review, 30-38.

Uruakpa, J.A. (1996). The Anglican Church and educational development in the eastern states of Nigeria. In S.N Adiele (Ed.). The Niger mission: Origin, growth and impact, 1857-1995 (pp. 129-141). Aba: Isaeco.

Wyse, AJ.G. (1988). The Krio factor in West African history. The Calabar Historical Journal, 31, 17-32. 
